American J. of Engineering and Applied Sciences 1 (4): 302-311, 2008

ISSN 1941-7020

(C) 2008 Science Publications

\title{
A Technical Review of Compressed Natural Gas as an Alternative Fuel for Internal Combustion Engines
}

\author{
Semin, Rosli Abu Bakar \\ Automotive Excellent Center, Faculty of Mechanical Engineering, \\ University Malaysia Pahang, Locked Bag 12, 25000 Kuantan, Pahang, Malaysia
}

\begin{abstract}
Natural gas is promising alternative fuel to meet strict engine emission regulations in many countries. Compressed natural gas $(\mathrm{CNG})$ has long been used in stationary engines, but the application of CNG as a transport engines fuel has been considerably advanced over the last decade by the development of lightweight high-pressure storage cylinders. Engine conversion technology is well established and suitable conversion equipment is readily available. For spark ignition engines there are two options, a bi-fuel conversion and use a dedicated to $\mathrm{CNG}$ engine. For compression ignition engines converted to run on natural gas, there are two main options discussed, there are dual-fuel engines and normal ignition can be initiated. Natural gas engines can operate at lean burn and stoichiometric conditions with different combustion and emission characteristics. In this paper, the CNG engines research and development fueled using CNG are highlighted to keep the output power, torque and emissions of natural gas engines comparable to their gasoline or diesel counterparts. The high activities for future $\mathrm{CNG}$ engines research and development to meet future $\mathrm{CNG}$ engines is recorded in the paper.
\end{abstract}

Keywords: Compressed natural gas, alternative fuel, engine development

\section{INTRODUCTION}

Natural gas is produced from gas wells or tied in with crude oil production. Natural gas (NG) is made up primarily of methane $\left(\mathrm{CH}_{4}\right)$ but frequently contains trace amounts of ethane, propane, nitrogen, helium, carbon dioxide, hydrogen sulfide, and water vapor. Methane is the principal component of natural gas. Normally more than $90 \%$ of natural gas is methane ${ }^{[6-}$ ${ }^{11]}$, the detail of natural gas compositions as shown in Table 1. by Shasby ${ }^{[42]}$. But, according to Srinivasan ${ }^{[44]}$, that in the natural gas composition more than $98 \%$ is methane. Natural gas can be compressed, so it can stored and used as compressed natural gas (CNG). CNG requires a much larger volume to store the same mass of natural gas and the use of very high pressure on about 200 bar or 2,900 $\mathrm{psi}^{[3]}$. Natural gas is safer than gasoline in many respects ${ }^{[2]}$. The ignition temperature for natural gas is higher than gasoline and diesel fuel. Additionally, natural gas is lighter than air and will dissipate upward rapidly if a rupture occurs. Gasoline and diesel will pool on the ground, increasing the danger of fire. Compressed natural gas is non-toxic and will not contaminate groundwater if spilled. Advanced compressed natural gas engines guarantee considerable advantages over conventional gasoline and diesel engines $^{[7]}$. Compressed natural gas is a largely available form of fossil energy and therefore non-renewable. However, CNG has some advantages compared to gasoline and diesel from an environmental perspective. It is a cleaner fuel than either gasoline or diesel as far as emissions are concerned. Compressed natural gas is considered to be an environmentally clean alternative to those fuels ${ }^{[6,7]}$.

Tabel 1. Natural Gas composition ${ }^{[42]}$

\begin{tabular}{llcccc}
\hline \multirow{2}{*}{$\begin{array}{c}\text { Compositi } \\
\text { on }\end{array}$} & Formula & \multicolumn{5}{c}{ Volume Fraction (\%) } \\
\cline { 3 - 6 } & & Ref. & Ref. & Ref. & Ref. \\
\hline Methane & $\mathrm{CH}_{4}$ & 94.00 & $\mathbf{2}$ & $\mathbf{3}$ & $\mathbf{4}$ \\
Ethane & $\mathrm{C}_{2} \mathrm{H}_{6}$ & 3.30 & 4.66 & 34.39 & 91.82 \\
Propane & $\mathrm{C}_{3} \mathrm{H}_{8}$ & 1.00 & 1.13 & 0.57 & - \\
Iso-Butane & i- & 0.15 & 0.21 & 0.11 & - \\
& $\mathrm{C}_{4} \mathrm{H}_{10}$ & & & & \\
N-Butane & $\mathrm{n}-$ & 0.20 & 0.29 & 0.15 & - \\
& $\mathrm{C}_{4} \mathrm{H}_{10}$ & & & & \\
Iso- & $\mathrm{i}-$ & 0.02 & 0.10 & 0.05 & - \\
\hline
\end{tabular}

Corresponding Author: $\quad$ Semin, Automotive Excellent Center, Faculty of Mechanical Engineering, University Malaysia Pahang, Locked Bag 12, 25000 Kuantan, Pahang, Malaysia, Tel: +609-5492217, Fax: +609-5492244, 


\begin{tabular}{llllll}
\hline Pentane & $\mathrm{C}_{5} \mathrm{H}_{12}$ & & & & \\
N-Pentane & n- & 0.02 & 0.08 & 0.06 & - \\
& $\mathrm{C}_{5} \mathrm{H}_{12}$ & & & & \\
Nitrogen & $\mathrm{N}_{2}$ & 1.00 & 1.02 & 0.96 & 4.46 \\
$\begin{array}{l}\text { Car.Dioxi } \\
\text { de }\end{array}$ & $\mathrm{CO}_{2}$ & 0.30 & 0.26 & 0.28 & 0.81 \\
Hexane & $\mathrm{C}_{6}+$ & 0.01 & 0.17 & 0.13 & - \\
& $\left(\mathrm{C}_{6} \mathrm{H}_{14}\right.$ & & & & \\
& ) & & & & \\
$\begin{array}{l}\text { Oxygen } \\
\text { Carbon }\end{array}$ & $\mathrm{O}_{2}$ & - & 0.01 & $<0.01$ & - \\
$\begin{array}{l}\text { Monoxide } \\
\text { Total }\end{array}$ & - & - & $<0.01$ & $<0.01$ & - \\
& & 100 & 100 & 100 & 100 \\
\hline
\end{tabular}

Compressed natural gas (CNG) has long been used in stationary engines, but the application of $\mathrm{CNG}$ as a transport engines fuel has been considerably advanced over the last decade by the development of lightweight high-pressure storage cylinders ${ }^{[5]}$. Any researcher ${ }^{[42-46]}$ was researched about the compressed natural gas as alternative fuel motivated by the economic, emissions and strategic advantages of alternative fuels. Several alternative fuels have been recognized as having a significant potential for producing lower overall pollutant emissions compared to gasoline and diesel fuel. Natural gas, which is composed predominately by has been identified as a leading candidate for transportation applications among these fuels for several reasons ${ }^{[42-44]}$. Shasby ${ }^{[42]}$ identified tree reason, the first reason is availability, the second attraction reason of natural gas is its environmental compatibility and the third attraction reason of natural gas is that it can be used in conventional diesel and gasoline engines. According to ${ }^{[5]}$, operating costs are another reasons, where natural gas powered vehicles theoretically have a significant advantage over petroleum-powered vehicles, the basis for this argument is the lower cost per energy unit of natural gas as compared to petroleum. The argument is somewhat more complex than this, however. While it is true that in the vast majority of the country natural gas is cheaper than gasoline or diesel, the analysis plays out differently. Compressed Natural Gas (CNG) is attractive for five reasons. (1) It is the only fuel cheaper than gasoline or diesel. (2) It has inherently lower air pollution emissions. (3) It has lower greenhouse gas emissions. (4) Its use extends petroleum supplies, and (5) there are large quantities of the fuel available in North America. The difficulties with CNG arise from vehicle range, fuel storage, infrastructure costs, and ensuring sufficient supply. The importance of range as a vehicle characteristic is illustrated $\mathrm{in}^{[23]}$. In this case $^{[23]}$, the additional weight of batteries or storage cylinders requires considerable extra chassis weight, requiring still more fuel and storage cylinders or batteries. A large increase in the number of CNG vehicles would require new gas pipelines and other infrastructure. Although natural gas reserves are large, it is not clear whether extraction could be doubled over many years without an increase in extraction cost.

According to Lave ${ }^{[49]}$, the compressed natural gas vehicles exhibit significant potential for the reduction of gas emissions and particulates. There are any problems for compressed natural gas applications such as onboard storage due to low energy volume ratio, knock at high loads and high emission of methane and carbon monoxide at light loads. However, these can be overcome by the proper design, fuel management and exhaust treatment techniques. The CNG fuel properties and characteristics are shown in Table 2.

\begin{tabular}{|c|c|}
\hline CNG Properties & Value \\
\hline Density $\left(\mathrm{kg} / \mathrm{m}^{3}\right)$ & 0.72 \\
\hline Flammability limits (volume $\%$ in air) & $4.3-15$ \\
\hline Flammability limits $(\varnothing)$ & $0.4-1.6$ \\
\hline Autoignition temperature in $\operatorname{air}\left({ }^{0} \mathrm{C}\right)$ & 723 \\
\hline Minimum ignition energy $(\mathrm{mJ})^{\mathrm{b}}$ & 0.28 \\
\hline Flame velocity $\left(\mathrm{ms}^{-1}\right)^{\mathrm{b}}$ & 0.38 \\
\hline Adiabatic flame temperature $(\mathrm{K})^{\mathrm{b}}$ & 2214 \\
\hline Quenching distance $(\mathrm{mm})^{\mathrm{b}}$ & 2.1 \\
\hline Stoichiometric fuel/air mass ratio & 0.069 \\
\hline Stoichiometric volume fraction $\%$ & 9.48 \\
\hline Lower heating value $(\mathrm{MJ} / \mathrm{kg})$ & 45.8 \\
\hline Heat of combustion $\left(\mathrm{MJ} / \mathrm{kg}_{\text {air }}\right)^{\mathrm{b}}$ & 2.9 \\
\hline
\end{tabular}

Most existing compressed natural gas vehicles use petrol engines, modified by after-market retrofit conversions and retain bi-fuel capability. Bi-fuelled vehicle conversions generally suffer from a power loss and can encounter driveability problems, due to the design and/or installation of the retrofit packages ${ }^{[5]}$. In bi-fuel for diesel engine, natural gas as a fuel for diesel engines offers the advantage of reduced emissions of nitrogen oxides, particulate matter, and carbon dioxide while retaining the high efficiency of the conventional diesel engine ${ }^{[5]}$. Single-fuel vehicles optimized for compressed natural gas are likely to be considerably more attractive in terms of performance, and somewhat more attractive in terms of cost. According to Poulton ${ }^{[5]}$ that a natural gas-powered, single-fuel vehicle should 
be capable of similar power, similar or higher efficiency and mostly lower emissions than an equivalent petrol-fuelled vehicle. Such a vehicle would have a much shorter driving range unless the fuel tanks are made very large, which would then entail a further penalty in weight, space, performance and cost. CNG vehicles' range limitations, however, would be eased considerably if LNG were substituted as the fuel.

\section{CNG AS A FUEL CHARACTERISTICS}

The octane rating of natural gas is about 130 , meaning that engines could operate at compression ration of up to $16: 1$ without "knock" or detonation. Many of the automotive makers already built transportation with a natural gas fuelling system and consumer does not have to pay for the cost of conversion kits and required accessories. Most importantly, natural gas significantly reduces $\mathrm{CO}_{2}$ emissions by $20-25 \%$ compare to gasoline because simple chemical structures of natural gas (primarily methane $-\mathrm{CH}_{4}$ ) contain one Carbon compare to diesel $\left(\mathrm{C}_{15} \mathrm{H}_{32}\right)$ and gasoline $\left(\mathrm{C}_{8} \mathrm{H}_{18}\right)^{[5,44]}$. Like methane and hydrogen is a lighter than air type of gas and can be blended to reduce vehicle emission by an extra $50 \%$. Natural gas composition varies considerably over time and from location to location ${ }^{[5]}$. Methane content is typically $70-90 \%$ with the reminder primarily ethane, propane and carbon dioxide ${ }^{[42,43]}$. At atmospheric pressure and temperature, natural gas exists as a gas and has low density. Since the volumetric energy density (joules $/ \mathrm{m}^{3}$ ) is so low, natural gas is often stored in a compressed state $(\mathrm{CNG})$ at high pressure stored in pressure vessels. The $\mathrm{CNG}$ as a fuel characteristics is shown in Table 3. below.

Table 3. CNG fuel characteristics ${ }^{[44]}$

\begin{tabular}{lc}
\hline CNG Characteristics & Value \\
\hline Vapour density & 0.68 \\
Auto Ignition & $700^{\circ} \mathrm{C}$ \\
Octane rating & 130 \\
Boiling point (Atm. Press) & $-162^{\circ} \mathrm{C}$ \\
Air-Fuel Ratio (Weight) & 17.24 \\
Chemical Reaction With Rubber & No \\
Storage Pressure & $20.6 \mathrm{Mpa}$ \\
Fuel Air Mixture Quality & Good \\
Pollution CO-HC-NOx & Very Low \\
Flame Speed m per sec & 0.63 \\
Combust. ability with air & $4-14 \%$ \\
\hline
\end{tabular}

According to Poulton ${ }^{[5]}$ that natural gas has a high octane rating, for pure methane the $\mathrm{RON}=130$ and enabling a dedicated engine to use a higher compression ratio to improve thermal efficiency by about 10 percent above that for a petrol engine, although it has been suggested that optimized CNG engine should be up to 20 percent more efficient, although this has yet to be demonstrated. Compressed natural gas therefore can be easily employed in sparkignited internal combustion engines. It has also a wider flammability range than gasoline and diesel oil ${ }^{[7]}$. Optimum efficiency from natural gas is obtained when burnt in a lean mixture in the range $A=1.3$ to 1.5 , although this leads to a loss in power, which is maximized slightly rich of the stoichiometric air/gas mixture. Additionally, the use of natural gas improves engine warm-up efficiency, and together with improved engine thermal efficiency more than compensate for the fuel penalty caused by heavier storage tanks. Natural gas must be in a concentration of $5 \%$ to $15 \%$ in order to ignite, making ignition in the open environment unlikely. The last and most often cited advantages have to do with pollution. The percentages vary depending upon the source, but vehicles burning natural gas emit substantially lesser amounts of pollutants than petroleum powered vehicles. Non-methane hydrocarbons are reduced by approximately $50 \%, \mathrm{NO}_{\mathrm{x}}$ by $50-87 \%, \mathrm{CO}_{2}$ by $20-30 \%, \mathrm{CO}$ by $70-95 \%$, and the combustion of natural gas produces almost no particulate matter ${ }^{[5]}$. Natural gas powered vehicles emit no benzene and 1,3-butadiene which are toxins emitted by diesel powered vehicles. The use of natural gas as a vehicle fuel is claimed to provide several benefits to engine components and effectively reduce maintenance requirements. It does not mix with or dilute the lubricating oil and will not cause deposits in combustion chambers and on spark plugs to the extent that the use of petrol does, thereby generally extending the piston ring and spark plug life. In diesel dual-fuel operation evidence of reduced engine wear is reported, leading to expected longer engine life ${ }^{[3]}$. The use of natural gas in a diesel spark-ignition (SI) conversion is expected to allow engine life at least as good as that of the original diesel engine. Because of its very low energy density at atmospheric pressure and room temperature, natural gas must be compressed and stored on the vehicle at high pressure - typically $20 \mathrm{MPa}, 200$ bar or 2,900 psi. The alternative storage method is in liquid form at a temperature of $-162^{\circ} \mathrm{C}$. Because of the 
limited capacity of most on-board CNG storage systems a typical gas-fuelled vehicle will need refueling two to three times as often as a similar petrol or diesel-fuelled vehicle - a typical CNG-fuelled car engine will provide a range of 150-200 km and a truck or bus some 300-400 $\mathrm{km}$. It is possible that the space required and weight of CNG fuel storage systems will fall in the future as a result of improved engine efficiencies as with dedicated designs and lightweight storage tanks ${ }^{[5]}$.

CNG vehicles range limitations would be eased considerably if LNG were substituted as the fuel. Rather than CNG 4:1 volume disadvantage with petrol, LNG has only a 1.3:1 disadvantage ${ }^{[5]}$. Even with the required insulation to ensure cryogenic storage, and the added bulk it causes, advanced LNG fuel tanks should be only about twice as bulky as petrol tanks storing the same energy. When a vehicle is operating on CNG about 10 percent of the induced airflow is replaced by gas which causes a corresponding fall in engine power output. In performance terms the converted bi-fuel engine will generally have a $15-20$ percent maximum power reduction than that for the petrol version. When a diesel engine conversion is fuelled on gas more engine power can be obtained due to the excess air available which, due to smoke limitations, is not fully consumed. Because natural gas has a low cetane rating, a spark ignition conversion for diesel engines is required, adding to the conversion $\operatorname{cost}^{[5]}$. Even though more power may be available, experience has shown that SI diesel engine conversions are usually down-rated to prevent excessive combustion temperatures leading to component durability problems. A diesel/gas dual-fuel conversion may experience a loss of efficiency, relative to diesel-fuelling alone. A 15-20 percent loss in thermal efficiency was reported in a dual-fuel heavy-duty truck demonstration in Canada, where natural gas provided 60 percent of the total fuel requirement during dual-fuel operation $^{[5]}$. A further disadvantage of methane is that it is a greenhouse gas with a warming forcing factor many times that of the principal greenhouse gas, $\mathrm{CO}_{2}$, Gas leakage or vehicular emission, therefore, and the size of release, will have an impact on the overall greenhouse gas (GHG) emissions performance relative to the petrol or diesel fuel it substitutes ${ }^{[42-46]}$.

The safety aspects of converting vehicles to run on CNG are of concern to many people. However, the low density of methane coupled with a high auto-ignition temperature, $\mathrm{CNG}$ is $540^{\circ} \mathrm{C}$ compared with $227-500^{\circ} \mathrm{C}$ for petrol and $257^{\circ} \mathrm{C}$ for diesel fuel and higher flammability limits gives the gas a high dispersal rate and makes the likelihood of ignition in the event of a gas leak much less than for petrol or diesel. Additionally, natural gas is neither the toxic, carcinogenic nor caustic ${ }^{[5]}$. According to ${ }^{[5]}$ the legal maximum operating pressure for a vehicle storage cylinder will usually be in the range 20 to $25 \mathrm{MPa}$ commonly $20 \mathrm{MPa}$. Cylinders are tested before installation to a pressure of $30 \mathrm{MPa}$ (300 bar or 4,350 psi) or to a level to meet local requirements. Safety regulations specify a periodic re-inspection, typically at five-year intervals, including a pressure test and internal inspection for corrosion. According to ${ }^{[5]}$ there are two refueling modes with $\mathrm{CNG}$, the first is fast fill and the second is slow fill. The fast fill is where refueling times are comparable to those involved with conventional liquid fuels. Fast fill normally requires some buffer high pressure $(25 \mathrm{MPa})$ storage at the refueling station although an alternative is to use a compressor sized to fill vehicles directly without intermediate (or cascade) storage. A typical mediumsized refueling station with a compressor output around of $300 \mathrm{~m}^{3} /$ hour would be capable of servicing 30 buses or 300 cars over a 12-hour period. The slow fill is where one or more vehicles are connected directly to a low pressure supply via a compressor over relatively long time periods without the high pressure buffer storage facility. For many fleet operations the refueling installation will be located at the fleet garage with trickle fill dispensers located adjacent to the vehicle parking spaces. A CNG vehicle will be refueled two to three times as often as a similar petrol or diesel counterpart. This has obvious implications for $\mathrm{CNG}$ refueling station site and local traffic flow constraints. The fact that gas is delivered by pipeline rather than by tanker, however, alleviates both traffic flow and road hazards. An additional consideration is the cost of connection to a gas pipeline having the pressure and flow capacity to meet the demand.

\section{CNG ENGINES DEVELOPMENT}

The technology of engine conversion is well established and suitable conversion equipment is readily available. For petrol engines or spark ignition engines there are two options, a bi-fuel conversion and use a dedicated to $\mathrm{CNG}$ engine. The bi-fuel conversion of vehicles fitted with fuel-injected engines may utilize the original engine management system, if it can be modified to control the gas flow and revised ignition 
timing or alternatively, be fitted with a standard CNG control system. The fuel injectors must be disabled when the engine is running on gas, although fuel must still flow to the injectors and then pass directly to the return fuel line to provide cooling. The bi-fuel engines of the spark ignition petrol engines according to Poulton ${ }^{[5]}$ is of all sizes can be converted to natural gas by the fitting of a gas carburetor / mixer, regulator, shut-off valves, control system and fuel storage tanks. A bi-fuel arrangement exists when the petrol fuel system is retained, but this prevents the engine being fully optimized for the high-octane gas. This arrangement does provide a back-up fuel where CNG refueling facilities are not well developed. Dedicated natural gas engines is the engine dedicated to mono fuel of natural gas engines, there are optimized for the natural gas fuel. They can be derived from petrol engines or may be specifically designed for the purpose.

With diesel engines converted or designed to run on natural gas, there are two main options discussed. The first is dual-fuel engines. These refer to diesel engines operating on a mixture of natural gas and diesel fuel. Natural gas has a low cetane rating and is not therefore suited to compression ignition, but if a pilot injection of diesel occurs within the gas/air mixture, normal ignition can be initiated. Between 50 and 75 percent of usual diesel consumption can be replaced by gas when operating in this mode. The engine can also revert to 100 percent diesel operation. The second is dedicated natural gas engines. Dedicated natural gas engines are optimized for the natural gas fuel. They can be derived from petrol engines or may be designed for the purpose. Until manufacturer original equipment (OE) engines are more readily available, however, the practice of converting diesel engines to spark ignition will continue, which involves the replacement of diesel fuelling equipment by a gas carburettor and the addition of an ignition system and spark plugs. Buses and trucks larger and greater numbers of cylinders are used than for light-duty engines. For compression ignition engines conversions to spark ignition, the pistons must be modified to reduce the original compression ratio and a high-energy ignition system must be fitted. The system is suitable for $\mathrm{CNG}$ and is ideally suited to timed (sequential) port injection system but can also be used for single point and low pressure in-cylinder injection. Gas production provides greater precision to the timing and quantity of fuel provided, and to be further developed and become increasingly used to provide better fuel emissions performance ${ }^{[5]}$.

An approximate measure of the equivalent petrol or diesel fuel capacity of a cylinder filled with gas at 20 Map have be obtained by dividing the cylinder volume by 3.5 - thus a 60 -litre cylinder will provide the energy equivalent of 17 liters of conventional fuel ${ }^{[5]}$. The design and installation of appropriate high-pressure onboard storage cylinders plays an important part of the efficient and safe operation of natural gas-fuelled vehicles. The cost constitutes a significant proportion of total vehicle installation cost. Most commonly used are chrome molybdenum steel gas cylinders, which are the cheapest, but one of the heaviest forms of storage container. It is possible that the space required and weight of CNG fuel storage systems will fall in the future result of improved engine efficiencies (as with dedicated designs) and lightweight storage tanks. For example, fibre-reinforced aluminum alloy or even allcomposite CNG pressure tanks demonstrate significant weight saving over steel - up to 57 percent ${ }^{[5]}$. It is even possible to increase the stored fuel's energy density by, for example, increasing the storage pressure of the gas. Future dedicated gas-fuelled vehicles will benefit by the fuel storage system being integrated into the vehicle structure, taking up less of the storage space currently lost in conversions. One proposal for a future vehicle CNG storage system is the so-called "fortress frame". A modified vehicle frame structure, of significant crosssection, would be used to store the gas inside it at low pressure. Additionally, the frame would provide greater crash protection to the occupants ${ }^{[5]}$. Although the design is likely to be as "safe" as conventional CNG vehicles, product liability issues, especially in the US, make the future development of this concept uncertain. Research is in progress to use adsorbent materials in a tank to store natural gas which reduces the required pressure (from 200 bar for CNG currently, to around 30 bar) and thereby avoids the need for high-pressure compressors and provides more design flexibility for the tank. Many types of adsorbent materials have been considered, including activated carbon, zeolites, clays and phosphates. With activated carbon at pressures of $300-400$ psi (2-2,75 MPa or 20-27 bar), the percentage of natural gas adsorbed can be 10 to 15 percent of the weight of carbon. However, it has not yet been possible to find an adsorbent material which provides the same 
storage capacity of usable gas at the same cost, weight and volume as with high-pressure cylinders. Although LNG storage has been used in demonstration fleets, few NGVs are operating on LNG at present. Advances are being made in local bulk LNG storage and, when vehicles are able to refuel their cryogenic storage tanks from such LNG depots at a cost that is competitive with $\mathrm{CNG}$, more extensive used will be made of this form of storage. Until such time most vehicles using natural gas will store it in compressed form ${ }^{[5]}$.

Natural Gas has been tested as an alternative fuel in a variety of engine configurations. The four main engine types include the traditional premixed charge spark ignition engine, the lean burn engine, the dualfuel/pilot injection engine, and the direct injection engine $^{[6-56]}$. Significant research has been done on these engines, however the most promising of these, the direct injection engine requires further development in order to realize its full potential. There are any researchers were did this object with modification or redesign of the gasoline engines ${ }^{[7-13,35,53,54]}$, diesel engines $^{[20-28,40-42]}$ with Compressed Natural Gas (CNG) as an alternative fuel usage on experiment and computational modeling base to found the new engine with use in diversification fuel, high performance, low emission and low cost. For example, Shashikanta ${ }^{[6]}$, studied a $17 \mathrm{~kW}$, stationary, direct injection diesel engine has been converted to operate it as a gas engine using producer-gas and compressed natural gas (CNG) as the fuels on two different operational modes called SIPGE (Spark Ignition Producer Gas Engine) and DCNGE (Dedicated Compressed Natural Gas Engine).

Shashikantha ${ }^{[6]}$ results of conversion to SIPGE (or DCNGE) can be called a success since comparable power and efficiency could be developed. CNG operation of SIPGE yielded almost comparable power and higher efficiency, which establishes the fuel flexibility of the machine under spark ignition operation. The spark advance needed for producer-gas operation is much higher at $35{ }^{\circ} \mathrm{BTDC}$ as compared to compressed natural gas operation where it was 22 ${ }^{\circ}$ BTDC, compression ratio being same, i.e., 11.5:1 in both the cases. This indicates that with ignition timing adjustment almost full flexibility between the two extreme fuels, i.e., producer-gas and compressed natural gas is a feasible concept with the requisite gas induction fittings.

With qualitative load control mode that was used, the part load operation of the engine was a problematic area with producer-gas as well as CNG. The results do indicate the scope of improvement in part load performance, for example by resorting to quantitative control. Producer-gas as well as CNG operation of the converted spark ignition engine eliminates particulate emission reckoned in terms of smoke density. This is the most virtuous facet of spark ignition engines as compared to diesel or even dual-fuel operation. The $\mathrm{CO}$ and NOx emission of converted engine under operation of either gas are much lower as compared to diesel and dual -fuel operation. This proves, that SIPGE as well as DCNGE are much environment friendly machines. The $\mathrm{HC}$ emissions are comparable between $\mathrm{CI}$ and SI modes, i.e., both under diesel and dual-fuel, as well as producer-gas and $\mathrm{CNG}$ operations. The overall superiority of SIPGE (or DCNGE) concept pertaining to environmental pollution can be claimed on the basis of particulate elimination, lower NOx and lower CO.

$\mathrm{Kato}^{[7]}$ has been developed a new engine Toyota Camry that uses $\mathrm{CNG}$ as fuel by modifying the base 2.2-liter gasoline engine in the unmodified base engine, torque and power for $\mathrm{CNG}$ decrease compared to gasoline. The new engine has adopted a high compression ratio, intake valves with early closed timing, intake and exhaust valves with increased lift and a low back pressure muffler, which thereby restored the loss of engine power.

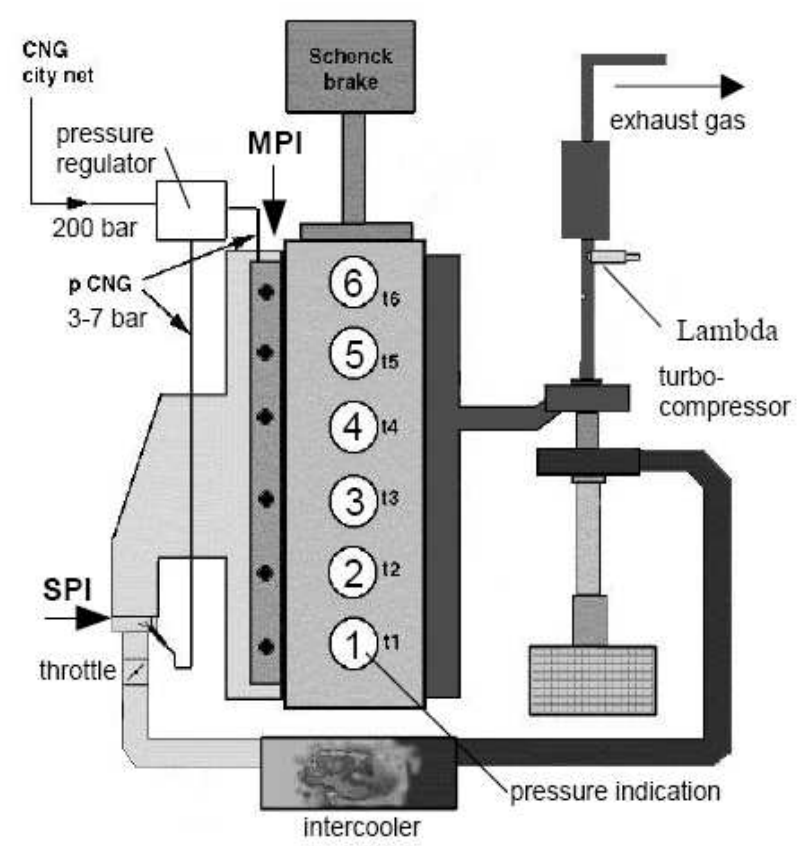

Fig. 1: gas injection system of CNG engine ${ }^{[40]}$ 
Figure 1 shows in order to greatly reduce exhaust emissions, a multi-port injection system was chosen by $^{[39,40]}$, and the injectors and pressure regulator have been newly developed. At the same time, precise airfuel $(\mathrm{A} / \mathrm{F})$ ratio control and special catalysts for CNG exhaust gas have been utilized. The resulting CNG engines output power has been restored to near that of the gasoline base engine. Lanni ${ }^{[24]}$ was compares and contrasts the emissions of buses powered by Detroit Diesel Series 50 diesel engines and Series 50G CNG engines. Wang ${ }^{[27]}$ developed of a $\mathrm{CNG}$ engine with ultra-lean-burn low emissions potential, hydrogenassisted jet ignition (HAJI) is used to achieve reliable combustion and low NOx emissions, whilst direct injection is used to improve thermal efficiency and decrease hydrocarbon (HC) emissions, it is found that port-inducted propane, port-inducted $\mathrm{CNG}$ and directly injected $\mathrm{CNG}$ all produce negligible levels of $\mathrm{CO}$ and NOx.

According to $\mathrm{Cho}^{[41]}$, there are several major problems needed to be solved when using lean burn natural gas engines. First, the set point for the best compromise between emissions and fuel economy is not clear, although wide range exhaust gas oxygen sensors have recently become available. Second, even if this set point is known for a given fuel and operating condition, the optimum air-fuel ratio changes with both operating conditions and fuel properties. Third, the exhaust temperatures of natural gas engines operating in lean burn conditions are below $750 \mathrm{~K}$ at most operating conditions, comparable to the base Diesel engines. The lower exhaust temperatures increase the difficulties in methane oxidation and result in low THC conversion efficiency. Numerous studies have suggested that decreasing the injector nozzle orifice diameter is an effective method of increasing fuel air mixing during injection.

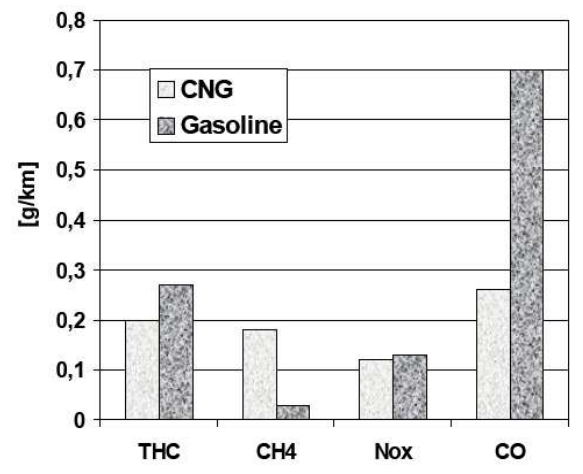

Fig. 2: CNG engine emissions result ${ }^{[12]}$

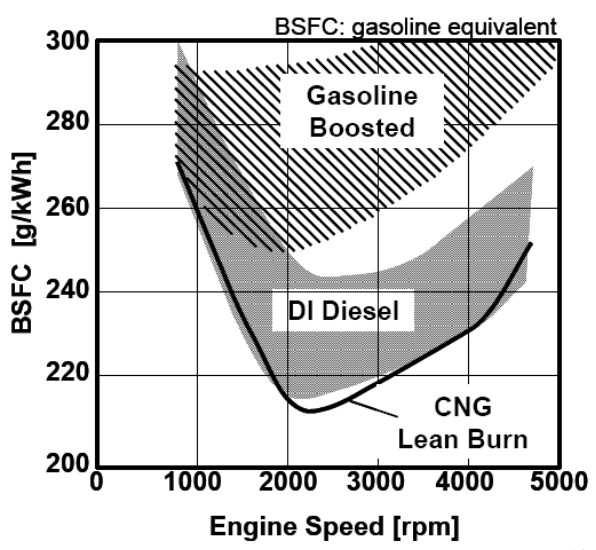

Fig. 3: CNG lean burn fuel consumption ${ }^{[12]}$

The vast majority of natural gas engines in use today are premixed charge spark ignition engines ${ }^{[12,542]}$. While spark ignited (SI) engines have significant advantages over diesel engines in terms of particulate and NOx emissions, there are several drawbacks with respect to performance, see Figure 2 and Figure 3. Premixed SI engines suffer $30 \%$ lower power output than equivalent size diesel engines due to knock limitations $^{[7]}$. In addition, SI engines suffer high pumping losses, due to the need to throttle the intake air at part load conditions. These factors result in a 15 to $30 \%$ reduction in volumetric efficiency as compared to diesel engines ${ }^{[36-43]}$. In diesel engine, Ouellette ${ }^{[56]}$ developed high pressure direct injection (hpdi) of natural gas in diesel engines, the result shown in Figure 4 that, natural gas or methane are reduced by about $40 \%$ over diesel operation NOx.

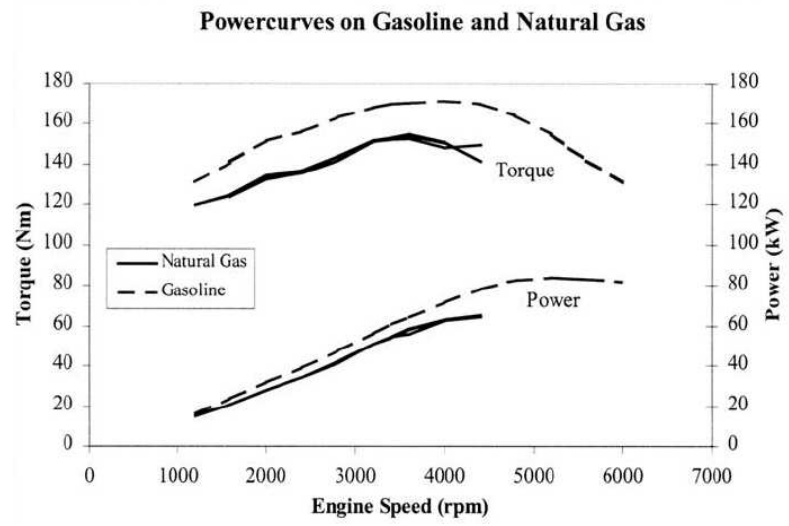

Fig. 4: CNG and Gasoline powercurves ${ }^{[55]}$

Figure 4 shows the Durell ${ }^{[55]}$ research result that, a 
9\% loss in peak torque when running on CNG compared to gasoline. Although peak power was not obtained on gas (due to the limitations of the injectors) there is also a predicted loss $9 \%$ on peak power.

Another significant drawback of the SI engines, if it is run at or near the stoichiometric air/fuel ratios, is the relatively high fuel consumption ${ }^{[41,}{ }^{42]}$. Improvements have been made in fuel consumption with the development of lean burn SI engines ${ }^{[53]}$. Experiments were carried out by $\mathrm{Chiu}^{[54]}$, one of the lean-burn natural gas ratings for this engine is $242 \mathrm{~kW}$ at $1950 \mathrm{rpm}$ and $1424 \mathrm{~N}-\mathrm{m}$, at $1250 \mathrm{rpm}$. This rating was also used for the stoichiometric natural gas engine.

Transient emissions and 13-mode, steady-state emissions tests were conducted on the engine on natural gas. The engine meets the transient emission standards for 2010 for NOx, NMHC, and CO on natural gas. Steady-state results on the 13-mode test show this engine meets $\mathrm{NOx}, \mathrm{NMHC}, \mathrm{CO}$ and particulate matter emissions standards for 2010 on natural gas. Formaldehyde emissions are well below the ULEV and transient bus standards for heavy-duty vehicles on both the transient and steady-state tests. Efficiency of the natural gas stoichiometric engine was comparable to a typical low emissions lean-burn natural gas engine. Results with gasoline were conducted on the first seven modes of the 13-mode, steady-state test. The engine did not meet the emissions standards for 2010 on gasoline for this testing. Catalyst degradation from misfires while setting up the engine to operate on gasoline contributed to the higher than expected emissions.

\section{CONCLUSIONS}

CNG is attractive for five reasons. It is the only fuel cheaper than gasoline or diesel. It has inherently lower air pollution emissions. It has lower greenhouse gas emissions. Its use extends petroleum supplies, and there are large quantities of the fuel available in the world. There are several major problems needed to be solved when using natural gas engines, there is the set point for the best compromise between emissions and fuel economy is not clear, the optimum air-fuel ratio changes with both operating conditions and fuel properties.

\section{REFERENCES}

1. Heywood, J.B., 1998. Internal Combustion Engine Fundamentals, McGraw-Hill, Singapore.
2. Kowalewicz, Andrzej., 1984. Combustion System of High-Speed Piston I.C. Engines, Wydawnictwa Komunikacji i Lacznosci, Warszawa.

3. Stone, Richard., 1997. Introduction to Internal Combustion Engines $2^{\text {nd }}$ Edition, SAE Inc., USA.

4. Ganesan, V., 1999. Internal Combustion Engines Second Edition, Tata McGraw-Hill, New Delhi.

5. Poulton, M.L., 1994. Alternative Fuels for Road Vehicles, Comp. Mechanics Publications, UK.

6. Shashikantha., Parikh P.P., 1999. Spark ignition producer gas engine and dedicated compressed natural gas engine-Technology development and experimental performance optimization, SAE Technical Paper 1999-01-3515.

7. Kato, Kichiro., Igarashi, Kohei., Masuda, Michihiko., Otsubo, Katsuji., Yasuda, Akio., Takeda, Keiso., Sato, Toru., 1999. Development of engine for natural gas vehicle, SAE Technical Paper 1999-01-0574.

8. Wayne, W. Scott., Clark, Nigel. N., Atkinson, Christopher. M., 1998. A parametric study of knock control strategies for a bi-fuel engine, SAE Technical Paper 980895.

9. Sun, Xiaobo., Lutz, Alwin., Vermiglio, Ezio., Arold, Mark., 1998. Wiedmann, Tom., The development of the General Motors 2.2L CNG bifuel passenger cars, SAE Technical Paper 982445.

10. Liu, Chung Y., Chen, Randy., Hussain, Syed F., 1998. Development of Gaseous Injector for Propane and CNG, SAE Technical Paper 981355.

11. de Carvalho, Remo.D.B., Valle, Ramón.M., Rodrigues, Vander.F., de Magalhaes, Francisco.E., 2003. Performance and emission analysis of the turbocharged spark-ignition engine converted to natural gas, SAE Technical Paper 2003-01-3726.

12. Pischinger, S., Umierski, M., Hüchtebrock, B., 2003. New CNG concepts for passenger cars: High torque engines with superior fuel consumption, SAE Technical Paper 2003-01-2264.

13. Catania, A. E., Misul, D., Spessa, E., Vassallo, A., , 2004. Analysis of combustion parameters and their relation to operating variables and exhaust emissions in an upgraded multivalve bi-fuel CNG SI engine, SAE Technical Paper 2004-01-0983.

14. White, C.M., Steeper, R.R., Lutz, A.E, 2006. The hydrogen-fueled internal combustion engine: a technical review, International Journal of Hydrogen Energy 31, pp. 1292-1305.

15. Hotta,Y., Nakakita, K., 1997. Combustion improvement for reducing exhaust emissions in IDI diesel engine, JSAE Review 18, pp. 19-31. 
16. Heffel, W.James., 2003. NOx emission reduction in a hydrogen fueled internal combustion engine at $3000 \mathrm{rpm}$ using exhaust gas recirculation, International Journal of Hydrogen Energy 28, pp. 1285-1292.

17. Sazhin, S.S., Feng, G., Heikal,M.R., 2001. A model for fuel spray penetration", Fuel 80, pp. 2171-2180.

18. Zuo, Chengji., Yang, Minggao., 1999. Operating characteristics and description of a dual-fuel engine for diesel-natural gas heavy-duty operation, SAE Technical Paper 1999-01-3523.

19. Li, G., Ouellette, P., Dumitrescu, S., Hill, P. G., 1999. Optimization study of pilot-ignited natural gas direct- injection in diesel engines, SAE Technical Paper 1999-01-3556.

20. Hollnagel, Carlos., Borges, Luiz.H., Muraro, Wilson., 1999. Combustion Development of the Mercedes-Benz MY1999 CNG-Engine M366LAG, SAE Technical Paper 1999-01-3519.

21. Xin, Zhang., J, Liu., Qiong, Wang., Zhuiqin, Hu., 1998. Study of Natural Gas Fueling of Locomotive Engines, SAE Technical Paper 981396.

22. Stanglmaier, R.H., Ryan, T.W., Souder, J.S., 2001. HCCI operation of a dual-fuel natural gas engine for improved fuel efficiency and ultra-low NOx emissions at low-to-moderate engine loads, SAE Technical Paper 2001-01-1897.

23. Hollnagel, C., Neto, J. A. M., Di Nardi, M. E., Wunderlich, C., Muraro, W., Miletovic, C., Bisetto, F., 2001. Application of the natural gas engines Mercedes-Benz in moving stage for the carnival 2001 in Salvador City, SAE Technical Paper 2001-01-3824.

24. Lanni, T., Frank, B.P., Tang, S., Rosenblatt, D., Lowell, D., 2003. Performance and emissions evaluation of compressed natural gas and clean diesel buses at New York City's Metropolitan Transit Authority", SAE Paper 2003-01-0300.

25. Ullman, T.L., Smith, L.R., Anthony, J.W., Slodowske, W.J., Trestrail, B., Cook, A. L.,Bunn, W.B., Lapin, C.A., Wright, K. J., Clark,.R., 2003. Comparison of exhaust emissions, including toxic air contaminants, from school buses in compressed natural gas, low-emitting diesel, and conventional diesel engine configurations, SAE Technical Paper 2003-01-1381.

26. Liu, Yi., Ali, Amr., Reitz, Rolf. D., 2004. Simulation of effects of valve pockets and internal residual gas distribution on HSDI diesel combustion and emissions, SAE Technical Paper 2004-01-0105.
27. Wang, D. E., Watson, H. C., 2000. Direct injection compressed natural gas combustion and visualization, SAE Technical Paper 2000-01-1838.

28. Chiodi, M., Berner, H., Bargende, M., 2004. Investigation on Mixture Formation and Combustion Process in a CNG-Engine by Using a Fast Response 3D-CFD-Simulation, SAE Technical Paper 2004-10-3004.

29. Bianchi, G. M., Richards, K., Reitz, R. D., 1999. Effects Of Initial Conditions In Multidimensional Combustion Simulations Of HSDI Diesel Engines", SAE Technical Paper 1999-01-1180.

30. Bianchi, G. M., Fontanesi, S., 2003. On The Applications of Low-Reynolds Cubic K-E Turbulence Models In 3D Simulations of ICE Intake Flows, SAE Technical Paper 2003-01-0003.

31. Riegler, U.G., Bargende, M., 2002. Direct coupled 1D/3D-CFD-computation (GT-Power/Star-CD) of the flow in the switch-over intake system of an 8cylinder SI engine with external exhaust gas recirculation, SAE Technical Paper 2002-01-0901.

32. Parvate-Patil, G.B., Hong, H., Gordon, B., 2003. An Assessment Of Intake And Exhaust Philosophies For Variable Valve Timing, SAE Technical Paper 2003-32-0078.

33. Sera, M.A., Bakar, R.A., Leong, S.K., 2003. CNG engine performance improvement strategy through advanced intake system, SAE Technical Paper 2003-01-1937.

34. Parvate-Patil, G. B., Hong, H., Gordon, B., 2004. Analysis of Variable Valve Timing Events and Their Effects on Single-Cylinder Diesel Engine, SAE Technical Paper 2004-01-2965.

35. Polášek, M., Macek, J., Takáts, M., Oldrich, V., 2002. Application of advanced simulation methods and their combination with experiments to modelling of hydrogen-fueled engine emission potentials, SAE Technical Paper 2002-01-0373.

36. Narayanaswamy, K., Rutland, C.J., 2004. Cycle Simulation Diesel HCCI Modelling Studies and Control, SAE Technical Paper 2004-01-2997.

37. Shiga, S., Ozone, S., Machacon, H. T. C., Karasawa, T., Nakamura, H., Ueda, T., Jingu, N., Huang, Z., Tsue, M., Kono, M., 2002. A Study of the Combustion and Emission Characteristics of Compressed-Natural-Gas Direct-Injection Stratified Combustion Using a RapidCompression-Machine, Combustion And Flame 129, pp.1-10.

38. Mbarawa, M., Milton, B.E., Casey, R.T., 2001. Experiments and modelling of natural gas combustion ignited by a pilot diesel fuel spray, Int. J. Therm. Sci. 40, pp. 927-936. 
39. Czerwinski J., Comte P., Janach.W., Zuber P., 1999. Sequential Multipoint Trans-Valve-Injection for Natural Gas Engines, SAE Technical Paper 1999-01-0565.

40. Czerwinski, J., Comte, P., Zimmerli, Y., 2003. Investigations of the Gas Injection System on a HD-CNG-Engine, SAE Paper 2003-01-0625.

41. Cho, H. M., He, Bang-Quan., 2007. Spark ignition natural gas engines-A review, Energy Conversion and Management 48, pp. 608-618.

42. Shasby, B.M., 2004. Alternative Fuels: Incompletely Addressing the Problems of the Automobile, MSc Thesis, Virginia Polytechnic Institute and State University, USA, pp: 5-13.

43. Brombacher, E.J., 1997. Flow Visualisation of Natural Gas Fuel Injection, Master of Applied Science Thesis, University of Toronto, Canada.

44. Srinivasan, K.K., 2006. The Advanced Injection Low Pilot Ignited Natural Gas Engine: A Combustion Analysis", Journal of Engineering for Gas Turbines and Power, Vol.128(1), pp. 213-218.

45. Hill, P. G., Douville, B., 2000. Analysis of Combustion in Diesel Engines Fueled by Directly Injected Natural Gas, Journal of Engineering for Gas Turbines and Power, Vol. 122, pp. 143-149.

46. Aslam, M.U., 2006. An experimental investigation of $\mathrm{CNG}$ as an alternative fuel for a retrofitted gasoline vehicle, Fuel 85, pp. 717-724.

47. Fino, D., Russo, N., Saracco, G., Specchia, V, 2006. CNG engines exhaust gas treatment via PdSpinel-type-oxide catalysts", Catalysis Today 117, pp. 559-563.

48. Kubesh J. T., Podnar D. J, 1998. Ultra Low Emissions and High Efficiency from an OnHighway Natural Gas Engine, SAE Technical Paper 981394.
49. Lave, L.B., MacLean, H., Lankey, R., Joshi, S., McMichael, F., Horvath, A., Hendrickson, C., 2000. Life cycle inventories of conventional and alternative automobile fuel/propulsion systems: Summary \& conclusions, SAE Technical Paper, 2000-01-1504.

50. Sunil, P., 2000. Practical Guide to Pressure Vessel Manufacturing", Marcel n Dekker.

51. ISO 11439:2000. Gas cylinders - High pressure cylinders for the on-board storage of natural gas as a fuel for automotive vehicles. First Edition.

52. Furutani, M., Isogai, T., Ohta, Y., 2003. Ignition characteristics of gaseous fuels and their difference elimination for SI and HCCI gas engines, SAE Technical Paper 2003-01-1857.

53. Kawabata, Yasuharu., Mori, Daichi., 2004. Combustion diagnostics and improvement of a prechamber lean-burn natural gas engine, SAE Technical Paper, 2004-01-0979.

54. Chiu, J.P., 2004. Low Emissions Class 8 HeavyDuty, On-Highway Natural Gas and Gasoline Engine, SAE Technical Paper, 2004-01-2982.

55. Durell, Elizabeth., Allen, Jeff., Law, Donald., Heath, John., 2000. Installation and Development of a Direct Injection System for a Bi-Fuel Gasoline and Compressed Natural Gas Engine, Proceeding ANGVA 2000 Conference, Yokohama, Japan.

56. Ouellette, Patric., 2000. High Pressure Direct Injection (HPDI) of Natural Gas in Diesel Engines, Proceeding ANGVA 2000 Conference, Yokohama, Japan. 